\title{
Patient Sample Problem
}

National Cancer Institute

\section{Source}

National Cancer Institute. Patient Sample Problem. NCI Thesaurus. Code C139467.

Problems that occurred due to endogenous or exogenous interferent in the sample, or unexpected variation in the target analyte/marker. 